\title{
Współuczestnictwo rodziców i nauczycieli w realizacji założeń edukacji wielo- i międzykulturowej - (nie)możliwe rozwiązania
}

Streszczenie: Zagadnienie współuczestnictwa rodziców i nauczycieli w realizacji założeń edukacji wielo- i międzykulturowej nie należy do mocno wyeksponowanych w literaturze przedmiotu. Autorka artykułu podejmuje próbę przybliżenia typów partycypacji obu stron we wskazany obszar edukacyjny, korzysta z koncepcji rodzajów uczestnictwa rodziców i nauczycieli we wspólnym kształceniu i wychowaniu Volkera Krumma. Koncepcja ta stanowi podstawę do przedstawienia w analogiczny sposób czynnej i biernej partycypacji rodziców i nauczycieli w realizację wytycznych z zakresu edukacji wielo- i międzykulturowej, z jednoczesnym określeniem, które z tych typów, z jakich względów, mogą być podejmowane $\mathrm{z}$ większym/mniejszym powodzeniem.

Słowa kluczowe: współuczestnictwo, rodzina, szkoła, edukacja wielo- i międzykulturowa

\section{Edukacja wielo- i międzykulturowa - wspólny obszar zain- teresowań rodziny i szkoły}

Szkoła i rodzina, pomimo tego, że stanowią odrębne systemy, dzięki współpracy mogą zracjonalizować i ujednolicić swoje oddziaływania wychowawczo-edukacyjne, czyli stworzyć atrakcyjniejsze, odpowiednio zmodyfikowane i dostosowane warunki sprzyjające:

a) nabywaniu przez ucznia wiedzy i umiejętności w określonym zakresie, osiąganiu postępów w nauce,

b) rozwijaniu jego umiejętności o charakterze społecznym i interpersonalnym - umiejętności współdziałania w zespole, pracy w grupie, budowania więzi międzyludzkich, umiejętności brania na siebie odpowiedzialności za swe postępowanie (Lewandowska-Kidoń, 2005, s. 53),

c) przyswajaniu przez ucznia kompetencji kulturowych - umiejętności potrzebnych do życia w rodzinie, w społeczności lokalnej i w demokra- 
tycznym państwie, zgodnie z przekazem tradycji kulturowej (Lewandowska-Kidoń, 2005, s. 53). „Osoba kompetentna kulturowo swobodnie „porusza się” we własnej kulturze, ma świadomość różnic między kulturami i w związku z tym uświadamia sobie własne przekonania odnoszące się do nich oraz reakcje na odmienność w sytuacji kontaktu kulturowego" (Suchocka, 2016, s. 124).

Kształtowanie kompetencji kulturowych stanowi niezaprzeczalny fundament pod nabywanie i rozwijanie kompetencji międzykulturowych, na które składa się nie tylko wiedza na temat własnego, ale też obcego świata kulturowego, a przy tym umiejętności radzenia sobie w kontakcie z przedstawicielami innych kultur oraz postawy - empatia, gotowość do nawiązywania relacji z osobą odmienną, otwartość poznawcza. Zestawienie węzłowych kompetencji międzykulturowych opracował Mariusz Korczyński (2017); zaliczył do nich: kompetencje komunikowania się (znajomość języków obcych, dowcip, efektywność komunikacji, uśmiechanie się, uważne słuchanie), inteligencję emocjonalną (empatia, adaptacja i elastyczność zachowań, radzenie sobie z uczuciami, elastyczność interpersonalna), rozumienie zachowań innych kulturowo partnerów (zdolność do zrozumienia Innych, interakcja kulturowa, współpraca i udział w kulturze, otwartość na nowe informacje), otwartość na odmienność (pozytywne nastawienie, otwartość na Innych, tolerancja, uprzejmość), umiejętność rozwiązywania konfliktów (umiejętność zarządzania interakcją, możliwość dostosowania do różnych kultur, umiejętność radzenia sobie ze stresem, zasady grzeczności), umiejętność radzenia sobie w niepewnych sytuacjach (umiejętność nawiązywania relacji interpersonalnych, świadomość siebie i innych, zaangażowanie). Potrzeba przyswajania kompetencji międzykulturowych przez współczesnego człowieka podyktowana zostaje złożonością życia społecznego i ujawniającą się w coraz to większym stopniu heterogenicznością kulturową. „Procesy globalizacji różnych sfer działalności, integracja państw i społeczeństw, masowe migracje, liczne kontakty (i te bezpośrednie, i te za pośrednictwem środków przekazu informacji) z ludźmi różnych narodowości, kultur, o odmiennym od naszego kolorze skóry - słowem Innym - skłaniają do bliższego poznania tych ludzi i stworzonych przez nich kultur" (Lewowicki i Suchodolska, 2011, s. 7).

Wobec powyższego podjęty został w niniejszym tekście namysł nad współdziałaniem rodziny i szkoły uwzględniający dynamikę zjawisk rozgrywających się w określonym czasie i przestrzeni życia społecznego. Nie można prowadzić rozważań na ten temat z pominięciem kontekstu socjokulturowego, widocznych przemian i zjawisk społecznych - np. warunki wolnorynko- 
we, ekspansja kultury indywidualistycznej, pluralizm aksjologiczny i zmiany w systemie wartości moralnych (Opozda, 2017, s. 33) - w tym również istniejącego świata wielokulturowego ujmowanego „w sposób bliski bachtinowskiemu rozumieniu pogranicza kultur, a więc styku i zderzenia kultur nie tylko między różnymi narodami czy grupami etnicznymi, ale także - a może głównie - między ludźmi o różnym wykształceniu, doświadczeniach życiowych, wyznaniach, statusie społecznym itp." (Lewowicki, 2013, s. 33). Pod tym względem również w kręgu zainteresowań rodziny i szkoły ważne są wspólne ustalenia i działania z zakresu edukacji wielo- i międzykulturowej, która „daje możliwość podtrzymywania, chronienia i rozwijania różnych kultur” (Lewowicki, 2008, s. 21), a zarazem prowadzi „do otwarcia się na inne społeczności i kultury, do możliwie szerokiego poznawania Innego i ich kultur, do wzajemnego czerpania z dorobku, do wzajemnego wspierania kultur" (Lewowicki, 2008, s. 21). W głównej mierze są to działania sprzyjające nabywaniu oraz podtrzymywaniu wskazanych kompetencji międzykulturowych i koncentrują się one na trzech głównych zakresach uwrażliwiania kulturowego $^{1}$ (Lewowicki, 2008, s. 18). Pierwszy kładzie nacisk na poznanie i zrozumienie własnego dziedzictwa kulturowego (zakres podkreślający konieczność realizacji edukacji regionalnej, narodowej). Wiąże się z troską o przekaz i podtrzymywanie obyczajów, tradycji, wartości wewnątrzrodzinnych, lokalnych, regionalnych i narodowych, oraz eksponuje dzieła kultury rodzimej i ich twórców, dorobek kulturowy narodu, dążąc do rozwijania poczucia przynależności do lokalnej, narodowej społeczności. Drugi - wdraża do zauważania i poznawania szeroko pojętego Innego ${ }^{2}$ (Grzybowski, 2008; Lewowicki, 2008), zaciekawienia odmiennością (tym samym stanowi nawiązanie do edukacji wielokulturowej i jej podtrzymywania). Wiedza na temat warunków życia codziennego osób odmiennych, ich systemów wartości, norm kulturowych i społecznych, konwencji społecznych, obyczajowości, specyfiki celebrowania uroczystości pozwala lepiej zrozumieć, że nie należy oceniać Innego z powodu różnic, i wiąże się w efekcie z rozbudzeniem większego zainteresowania Innym, zaufania do niego. Pod tym względem szczególnego

1 Zakresy sformułowano na podstawie, wskazanych przez Tadeusza Lewowickiego, trzech kategorii wyróżniających obszary edukacji: regionalizmu, wielokulturowości, międzykulturowości.

2 Przedstawiciela społeczności cechującego się odmiennym wyglądem, statusem społecznym, obyczajami, religią czy wyznaniem, pochodzeniem, będącego wyrazicielem określonych systemów wartości, poglądów politycznych, kodów językowych, wyróżniającego się stopniem niepełnosprawności czy wiekiem. 
znaczenia nabiera ostatni zakres, czyli otwarcie na Innych $i$ ich kultury, korzystanie z dorobku innych kultur, czyli uświadomienie sobie konieczności wejścia $w$ interakcję $z$ Innymi, podjęcia dialogu, wspótdziatania $z$ Innymi (znamienny w podejściu międzykulturowym). Przyczynia się do łatwiejszego i sprawniejszego wyjścia z sytuacji konfliktowej, napiętej oraz podjęcia współpracy mimo sprzeczności, różnic, albowiem „osoby reprezentujące wysoki poziom otwartości traktują odmienność jako cechę pozytywną, są chętne do uczenia się od innych i podejmują próby zrozumienia odmiennych (...) reprezentujące niski poziom otwartości odmienność postrzegają jako cechę negatywną i nie potrafią przyjąć i zrozumieć perspektywy postrzegania właściwej innym ludziom" (Mazur, 2012, s. 185).

Założenia edukacji wielo- i międzykulturowej realizowane są z większym powodzeniem w obrębie najbliższego środowiska wychowawczego: rodzinnego, szkolnego oraz w kontakcie z przedstawicielami lokalnej społeczności. Liczne badania - zebrane i omówione przez Ewę Ogrodzką-Mazur (2011) dostarczyły danych potwierdzających, że przekaz dzieciom i młodzieży tradycji, treści o regionie, tkwiących w nim zasobach, dobrach, wartościach kulturowych odbywa się przede wszystkim w rodzinie. Między innymi w wielu rodzinach ze zróżnicowanego kulturowo terenu Śląska Cieszyńskiego istnieje wysoka świadomość tego, „że wiedza o przeszłości i teraźniejszości regionu jest istotnym wyznacznikiem tożsamości kulturowej i zarazem narodowej" (Ogrodzka-Mazur, 2011, 49), a z drugiej strony jest wyraźna aprobata możliwości „wnoszenia nowych elementów do już utrwalonej, dotychczasowej tradycji życia rodzinnego" (Ogrodzka-Mazur, 2011, s. 52). Ponadto okazuje się, że w rodzinach doświadczających wewnętrznego zróżnicowania (małżeństwa niejednolite narodowościowo, wyznaniowo) dorastające pokolenie podczas procesu wychowania kształtuje bardziej umiejętności dochodzenia do porozumienia w trakcie spotkania $\mathrm{z}$ Innym, podejmowania z nim rozmów i negocjacji oraz współdziałania (Chojnacka-Synaszko, 2018). Doskonalenie tego typu umiejętności powinno mieć miejsce na terenie placówki oświatowej, w której stworzona jest przestrzeń do licznych, systematycznych kontaktów z przedstawicielami wielu kategorii odmienności. Różnorodna społeczność szkolna (uczniowska, nauczycielska) i dodatkowo usytuowanie szkoły w zróżnicowanym kulturowo środowisku (np. niejednorodnym wyznaniowo, narodowościowo, środowisku, w którym żyją grupy emigrantów czy mniejszości etniczne, na obszarach pogranicznych) stanowi podstawę do podjęcia przez szkołę, nauczycieli zadania, które wiąże się z realizowaniem edukacji nastawionej na wzajemne poznawanie ludzi, ich kultur, uzyskując tym sa- 
mym dostęp do zasobów Innych oraz możliwość rozwijania umiejętności patrzenia na otoczenie z uwzględnieniem wielu innych perspektyw. Obecność, włączenie się rodziców - z własnej inicjatywy lub inicjatywy nauczyciela - na etapie planowania i podejmowania tego zadania wydaje się bardzo ważne i uzasadnione. Każdy uczeń jest członkiem jakiejś rodziny i w jej obrębie doświadcza w różnym stopniu sytuacji społecznych, kulturowych. Wewnątrz struktury rodzinnej ma miejsce przekaz wartości, obyczajów, ale też może być utrzymywany większy/mniejszy dystans lub jego brak wobec poszerzania wzorców zachowania czy angażowania się w relacje z przedstawicielami wielu kategorii odmienności. Tego typu informacje są bardzo przydatne podczas organizacji i realizacji działań w zakresie edukacji wielo- i międzykulturowej na terenie placówki edukacyjnej. Ponadto dzięki wspólnie podejmowanym działaniom przez rodziców i nauczycieli istnieje możliwość stworzenia rodzinom przestrzeni do integracji - uzyskują one dostęp do poznania innych rodziców, innych rodzin, uczą się wzajemnie dostrzegać podobieństwa oraz różnice, stanowiąc dla siebie wzajemne bogactwo.

\section{Aktywna i bierna partycypacja rodziców i nauczycieli we wspólne kształcenie i wychowanie młodego pokolenia}

W wykazie wymagań wobec publicznych szkół i placówek przyjętych przez państwo widnieje założenie Rodzice sa partnerami szkoty lub placówki3. Tym samym rodzice zostali potraktowani jako integralna część szkoły, która „jawi się jako podmiot(y) instytucjonalny(ne), w ramach którego/których widoczne są działające jednostki” (Januszewska, Kulesza, Kwiatkowski, Odrowąż-Coates, Perkowska-Klejman, Wiatr, 2015, s. 98). Szkoła ma być przestrzenią, „która stwarza aktorom okazje do interakcji” (Januszewska, Kulesza, Kwiatkowski, Odrowąż-Coates, Perkowska-Klejman, Wiatr, 2015, s. 98) oraz „rozkłada akcent z wyłącznego zainteresowania działaniem i odtwarzaniem makrostruktur, również na podmiotowe, sprawcze, działania poszczegól-

3 Rozporządzenie Ministra Edukacji Narodowej z dnia 6 sierpnia 2019 r. zmieniające rozporządzenie w sprawie wymagań wobec szkół i placówek $-\mathbb{\$} 1$. W rozporządzeniu Ministra Edukacji Narodowej z dnia 11 sierpnia 2017 r. w sprawie wymagań wobec szkół i placówek (Dz. U. poz. 1611) w załączniku do rozporządzenia wprowadza się następujące zmiany: 1) w części II tabeli: c) wymaganie 6 i charakterystyka tego wymagania otrzymują brzmienie: Rodzice są partnerami szkoły lub placówki (Nie dotyczy branżowych szkół II stopnia, szkół policealnych oraz szkół i placówek dla dorosłych). 
nych aktorów" (Januszewska, Kulesza, Kwiatkowski, Odrowąż-Coates, Perkowska-Klejman, Wiatr, 2015, s. 97). Rodzice, będąc częścią społeczności konstytuującej instytucję szkolną, mają współdecydować w sprawach szkoły i uczestniczyć w podejmowanych działaniach, co wiąże się z zaoferowaniem im możliwości wyrażenia swoich spostrzeżeń, wymiany informacji, uskuteczniania pomysłów, rozwiązań, wprowadzania modyfikacji oraz prowadzenia negocjacji, interpretacji i analizy sytuacji. Umożliwienie każdej ze stron zabrania głosu, uwzględnianie zdania rodziców przez nauczycieli i odwrotnie to właściwości charakterystyczne dla koncepcji współpracy rodziców i nauczycieli, w której obie strony są dla siebie sprzymierzeńcami, „partnerami, dzielącymi wspólne doświadczenie i połączonymi wspólnym celem, jaki stanowi, najogólniej, dobro dziecka, a bardziej szczegółowo - jego edukacyjny i życiowy sukces" (Mendel, 2007, s. 7). Podjęcie indywidualnej obustronnej współpracy właśnie na rzecz rozwoju ucznia, wspierania i doceniania jego postępów stanowi kolejny oczekiwany kierunek działań szkoły (Rozporządzenie MEN, 2019). Należy odchodzić od bagatelizowania kwestii dotyczących współpracy rodziców i szkoły w zakresie kształcenia, wychowania, opieki nad dzieckiem, gdy w centrum stawia się cel, którym jest właściwy przebieg jego rozwoju, dzięki uwzględnianiu indywidualnych, potencjalnych właściwości dziecka oraz stymulowaniu i zwiększaniu jego możliwości.

Mając na uwadze partnerskie kontakty rodziców i nauczycieli, austriacki profesor Volker Krumm mówi nie tyle o współpracy między tymi stronami, ile o współuczestnictwie, partycypacji (Śliwerski, 2004, 46-48), rozumianej jako przejaw zaangażowania (zobowiązania się do czegoś, podjęcia się jakiegoś zadania, wciągnięcia się w coś). „Wspólne dzielenie się wiedzą, pomysłami, systematyczna pomoc, podział pracy, zamiana ról, możliwość dokonywania refleksji nad działalnością wszystkich partnerów edukacyjnych podnosi ich świadomość potencjału wspólnotowej i wieloaspektowej aktywności. Partycypacja działań stanowi najkorzystniejszy układ powiązań między elementami środowiska edukacyjnego i wychowawczego" (Dubis, 2019, s. 162).

Współuczestnictwo zawiera w sobie jednocześnie aktywny oraz bierny udział nauczycieli i rodziców we wspólnym wychowaniu i kształceniu uczniów. Zarówno w odniesieniu do rodziców, jak i nauczycieli Krumm wskazał cztery możliwe rodzaje zaangażowania się:

A) o charakterze czynnym, czyli:

- w przypadku rodziców, to oni sami się angażują, więc 1) przejawiają czynną partycypację w uczeniu się dziecka w domu (podejmują nie tylko wspólnie z dzieckiem realizację zadań zleconych do wykona- 
nia jako praca domowa, lecz dodatkowo odpowiednio aranżują przestrzeń (pomoce edukacyjne, literatura popularnonaukowa, programy i gry edukacyjne itp.) i proponują przemyślane lub spontaniczne działania o charakterze edukacyjnym, włączając się tym samym we wspólną i racjonalną organizację czasu wolnego z dzieckiem, w trakcie którego ono się rozwija, poszerza wiedzę i doskonali - powtarzając, ćwicząc - umiejętności); 2) czynnie angażują się w sytuację szkolną dziecka, gdyż interesują się tym, co dzieje się w szkole, odczuwają potrzebę partycypacji w procesach decyzyjnych, przejawiają chęć kontrolowania przebiegu edukacji dziecka i jego postępów, co wyraża się w tym, że inicjują spotkania, rozmowy z nauczycielem, z własnej inicjatywy pojawiają się na konsultacjach i zgłaszają propozycje przedsięwzięć w obrębie zespołu klasowego, czy na terenie szkoły;

- w przypadku nauczycieli, którzy również angażują się z własnej woli, można mówić o 1) czynnym zaangażowaniu się nauczycieli (z różną motywacją i zróżnicowanymi kwalifikacjami) w proces kształcenia i wychowania na terenie szkoły; 2) czynnej partycypacji nauczycieli $\mathrm{w}$ istotnych - z punktu widzenia edukacji szkolnej - sytuacjach wychowawczych w domu rodzinnym uczniów.

b) o charakterze biernym, czyli:

- w przypadku rodziców, którzy są angażowani przez nauczycieli, wyróżniono 1) bierne zaangażowanie się rodziców w sytuację szkolną, gdy nauczyciele zapraszają rodziców do podjęcia wspólnych działań, współpracy w rozwiązywaniu spraw szkolnych, uczniowskich w klasie, przekazują informacje o podejmowanych przedsięwzięciach, wydarzeniach (szkoleniach, imprezach, inicjatywach); 2) bierne uczestnictwo rodziców w uczeniu się dziecka w domu z inspiracji nauczycieli, którzy proszą rodziców, zachęcają ich do udzielania dziecku pomocy, dostarczając jednocześnie rodzicom wskazówek, zaleceń;

- w przypadku nauczycieli angażowanych przez rodziców wyłoniono 1) bierne zaangażowanie nauczycieli w proces uczenia się dzieci $\mathrm{w}$ domu, kiedy rodzice zwracają się do nich z prośbą o pomoc, radę w rozwiązywaniu ich problemów wychowawczych; 2) bierne angażowanie się nauczycieli w wydarzenia szkolne z inspiracji rodziców, którym zależy na poprawie jakości kształcenia dziecka w szkole.

Przywołana powyżej klasyfikacja typów uczestnictwa rodziców i nauczycieli we wspólnym kształceniu i wychowaniu młodego pokolenia sta- 
nowi, w dalej podejmowanych rozważaniach, podstawę do przedstawienia w analogiczny sposób czynnej i biernej partycypacji rodziców i nauczycieli w realizację wytycznych z zakresu edukacji wielo- i międzykulturowej, z jednoczesnym określeniem, które z tych typów, z jakich względów, mogą być podejmowane $\mathrm{z}$ większym/mniejszym powodzeniem. Zagadnienie zostało podjęte, gdyż analiza literatury przedmiotu pozwala stwierdzić, iż dominują raczej opracowania, w których oddzielnie przedstawia się kwestie dotyczące edukacji wielo- i międzykulturowej na gruncie środowiska rodzinnego, czy jej realizacji na terenie placówki edukacyjnej, ewentualnie dochodzi do dokonania porównań w tym zakresie. Brakuje zaakcentowania możliwej współpracy rodziny i szkoły w tym obszarze edukacyjnym. Wobec tego podjęto próbę uchwycenia warunków i czynników - właściwych zarówno dla rodziny (rodziców), jak i szkoły (nauczycieli) - determinujących partycypację czynną/bierną obu stron w realizacje treści edukacji wielo- i międzykulturowej, jednocześnie zaznaczając, że te typy zaangażowania (czynne/bierne) stanowią dla siebie wzajemne uzupełnienie, ewentualnie alternatywę, aniżeli stoją względem siebie w opozycji (lepszy-gorszy).

\section{Zaangażowanie (się) rodziców i nauczycieli w realizację założeń edukacji wielo- i międzykulturowej}

Analizując zaangażowanie się obu stron - nauczycieli i rodziców - w podjęcie wspólnych działań w obrębie zróżnicowanych obszarów funkcjonowania szkoły, klasy szkolnej, w obrębie wielu zakresów edukacyjnych, w tym między innymi w zakres edukacji wielo- i międzykulturowej, należy wziąć pod uwagę z jednej strony tendencje tkwiące w jednostce (czyli rodzicu, nauczycielu), które mobilizują ją do rozpoczęcia i kontynuacji określonego działania, a z drugiej - sprzyjające wspólnej realizacji działań wytyczne, warunki (Radziewicz-Winnicki, 2014, s. 24). Dogodną okolicznością dla zainicjowania i podtrzymania współpracy między nauczycielem i rodzicem jest uznanie w regulacjach prawnych partnerstwa, stawianie na równi korzyści i praw rodziców oraz nauczycieli w procesie kształcenia i wychowania młodego pokolenia. Mocno akcentowana zasada partnerstwa we współpracy rodziców ze szkołą, a w głównej mierze najpierw z nauczycielem-wychowawcą swego dziecka, może być/jest w przypadku rodziców odbierana jako zachęta, zaproszenie do połączenia wysiłków podczas ustalania i realizacji wspólnych celów (edukacyjnych, wychowawczych). Tym samym może ona być czynnikiem przyciągającym do czynnego zaangażowania się rodziców w organizację 
edukacji wielo- i międzykulturowej na terenie szkoły. Mogą oni w sposób bardziej otwarty, śmiały, z własnej inicjatywy podejmować kontakt z nauczycielem w celu:

- omówienia własnych doświadczeń w zakresie pielęgnowania treści, wartości wewnątrzrodzinnych, lokalnych, regionalnych, czy elementów kultury narodowej, kontynentalnej, globalnej oraz w zakresie kształtowania umiejętności bycia z drugim, bycia dla drugiego (odmiennego);

- stawiania pytań, poszukiwania rozwiązań, co w tym zakresie można jeszcze wprowadzić, udoskonalić, zmienić, jakie podejścia zastosować i dlaczego.

Rodzice mogą konsultować z nauczycielem (szerszym gronem pedagogicznym) propozycje podjęcia konkretnych inicjatyw na terenie szkoły - cyklicznych wydarzeń, imprez, tworzenie kół zainteresowań, wdrażanie projektów i propozycji metodycznych (warsztatów, szkoleń, otwartych lekcji) skoncentrowanych na obszarach ściśle wiążących się z edukacją wieloi międzykulturową. Tym samym będą przyczyniać się do wzbogacenia oferty, przedsięwzięć już podejmowanych przez czynnie angażujących się nauczycieli w realizację założeń z zakresu edukacji wielo- i międzykulturowej na terenie szkoły lub do zainicjowania biernego zaangażowania się nauczycieli w organizację (polepszenie jakości) tego rodzaju edukacji w szkole.

Zasygnalizowany powyżej rodzaj czynnego uczestnictwa rodziców w kreowanie szkolnej edukacji wielo- i międzykulturowej może być bardziej widoczny i cieszyć się większym powodzeniem, jeżeli uwzględni się specyfikę rodziny polegającą na tym, że jest to rodzina z obszaru pogranicza, który cechuje różnorodność (często narodowościowa, wyznaniowa), wzajemne długoletnie przenikanie się kultur i radzenie sobie jednostek, grup społecznych z sytuacją wielokulturowości, dzięki sprawdzonym, wypracowanym w oparciu o codzienne doświadczenia, wzorcom reakcji i interakcji. Zważywszy na to, że mogą funkcjonować tu zarówno rodziny odrzucające odmienne wzory kulturowe (o etnocentrycznym typie socjalizacji), jak i rodziny otwarte - np. rodziny mieszane - na zapożyczenia, odznaczające się tolerancyjnością wobec Innych, przy zachowaniu własnej odrębności kulturowej (Nikitorowicz, 2001), będzie dochodziło do czynnej partycypacji rodziców w realizację edukacji wielo- i międzykulturowej w środowisku domowym. Rodzice owszem mogą się skupić przede wszystkim na zaznajamianiu swych dzieci z rdzennymi wartościami, wzorami, tradycjami i odwoływać się do dziedzictwa kultury zastanej, ale też oprócz tych działań będą troszczyć się o uwrażliwianie młodego pokolenia na istniejącą wokół odmienność (uczyć kultury Innych 
w celu wyzbywania się ograniczających uprzedzeń i przełamywania etnocentrycznego podejścia, sposobu myślenia w kontaktach z Innymi).

Podobne podejście (czynne uczestnictwo w realizację założeń edukacji wielo- i międzykulturowej w szkole) może cechować nauczyciela podejmującego pracę w placówce oświatowej funkcjonującej na obszarze pogranicznym, bowiem ma możliwość stykania się na co dzień „z wieloma problemami wywoływanymi przez zróżnicowanie narodowościowe, kulturowe, czy wyznaniowe społeczności częściej i w większej skali niż ich koledzy z innych regionów" (Lewowicki, 2008, s. 23), a ponadto wyróżnia go duża wrażliwość na sprawy wielokulturowości, pojawiające się trudne sytuacje, i znacznie większe umiejętności kształtowania poprawnych relacji międzyludzkich i międzykulturowych (Lewowicki, 2008). Dodatkowo nauczyciel pracujący w takich warunkach, chcąc wyposażyć uczniów w kompetencje międzykulturowe i przygotować ich do kreowania rzeczywistości społecznej, może wykorzystać zasoby środowiska lokalnego. Wielokulturowe otoczenie szkoły oferuje duże możliwości do rozwoju uczniów i efektywniejszego nabywania umiejętności przydatnych w nawiązywaniu i podtrzymywaniu poprawnych stosunków z reprezentantami tego otoczenia. Wśród nich mogą się też znaleźć grupy imigrantów, których dzieci podejmują naukę w publicznej czy prywatnej szkole. Wówczas taki nauczyciel, z doświadczeniem zawodowym w warunkach wielokulturowego pogranicza może podjacć owocne próby angażowania tych rodziców we wspólny proces kształcenia i wychowania dziecka. Efektem jego poczynań może być na początku:

- bierne uczestnictwo rodziców w realizację edukacji wielo- i międzykulturowej na terenie szkoły - będzie ono dotyczyło raczej rodziców-migrantów, którzy z krajem przyjmującym łączą przyszłość swoją i swego dziecka, albowiem oni „przywiązują większą wagę do wyników szkolnych, zachęcają do dalszej nauki, uczenia się języka obcego" (Rabczuk, 2013, s. 46-47), a zatem mogą przejawiać większe zainteresowanie podtrzymywaniem kontaktu ze szkołą dziecka, włączać się w inicjatywy proponowane przez nauczyciela, który dodatkowo wspiera i podtrzymuje odpowiedni klimat;

- bierne uczestnictwo rodziców w realizacje założeń edukacji wieloi międzykulturowej w domu - raczej odnosi się do rodziców-migrantów, którzy pojawili się w kraju przyjmującym ze względu na nagły wyjazd (związany z działaniami wojennymi, klęskami żywiołowymi, prześladowaniami) i zarówno oni, jak i ich dzieci mają utrudnioną adaptację do nowych warunków oraz nieuregulowany status prawny, co 
sprawia też, że zainteresowanie rodziców kwestiami edukacji dziecka na terenie placówki edukacyjnej zostaje zepchnięte na dalszy plan.

W przypadku rodziców-migrantów widoczną cechą jest bariera językowa, która może znacznie utrudniać ich współpracę z nauczycielem, szkołą. „Rodzice jako podmioty edukacji, często nieznający języka polskiego, borykający się z problemami adaptacji i skutków migracji są trudnymi partnerami dla polskich nauczycieli" (Dobrowolska, 2015, s. 304). To oczywiście nie zwalania szkoły, która ma sprzyjać procesom integracji kulturowej, od podejmowania działań na rzecz usuwania tych barier, bowiem „możliwa jest pomoc tłumacza z danej wspólnoty, pośrednictwo dwujęzycznego ucznia lub nauczyciela uczącego języka i kultury języka pochodzenia migranta" (Rabczuk, 2013, s. 50). Dodatkowo pod tym względem przydatne mogą okazać się treści przetłumaczone i udostępnione rodzicom za pośrednictwem szkolnej strony internetowej, wiadomości wysyłane z dziennika elektronicznego oraz wykorzystywane media społecznościowe, komunikatory do bycia w kontakcie i nawiązywania wzajemnych relacji również online w trybie zdalnym, co poniekąd wiąże się z podjęciem (w sposób pośredni) czynnego zaangażowania się nauczyciela na terenie środowiska rodzinnego w poznanie specyfiki rodziny danego ucznia, we wsparcie tej rodziny w procesie adaptacji.

Pozostając przy osobie nauczyciela, duże znaczenie, jeśli chodzi o charakter jego partycypacji w realizację edukacji wielo- i międzykulturowej, mają przejawiane przez niego postawy wobec osób odmiennych i zadań z zakresu tego typu edukacji. „Pozytywne postawy nauczycieli wobec realizacji treści z zakresu edukacji międzykulturowej skłaniają do otwartości na różnice kulturowe, podejmowania współpracy z innymi podmiotami i głębsze zaangażowanie w pracę dydaktyczną" (Dobrowolska, 2015, s. 305). Uwzględniając takie dane, powinien być eksponowany - na etapie przygotowania do pracy w zawodzie nauczyciela, w trakcie dokształcania, doskonalenia zawodowego - wątek autorefleksji, refleksji, towarzyszący stale własnej pracy w zmieniających się sytuacjach (na terenie szkoły, w lokalnym środowisku), namysł nad podejmowanym wysiłkiem, systematyczną pracą nad sobą również ukierunkowaną w stronę rozwijania pożądanych postaw.

Z drugiej strony wymaga się od nauczyciela, od szkoły, podjęcia niezależnie od wszystkiego współpracy z rodzicami, w celu rozpoznania sytuacji rodzinnej dziecka, aby systematycznie zapewniać skuteczne wspieranie jego rozwoju (Rozporządzenie MEN, 2019). Z kolei w przypadku rodziców „realne zaangażowanie wiąże się (...) często z krzywdą dziecka lub z koniecznością działania na rzecz dobra dziecka. To są momenty wyzwalające zaangażowanie 
rodziców. Wychodząc każdorazowo od własnego dziecka - jego krzywdy lub dobra - rodzicielskie zaangażowanie może jednak ewoluować ku refleksji nad „wspólną sprawą" - nad zmianą warunków edukacji” (Mendel i Wiatr, 2018, s. 212). Wobec tego, mając na względzie szeroko pojęte dobro dziecka, rodzice mogą przekonać się do czynnej lub biernej partycypacji w realizację założeń z zakresu edukacji wielo- i międzykulturowej na terenie szkoły. Dzięki temu zyskają głębszy wgląd i potwierdzenie przydatności rozwijanych kompetencji międzykulturowych w codziennym życiu osobistym swego dziecka i w jego przyszłym życiu zawodowym. Przekonają się, że placówka edukacyjna (przy ich współudziale) planuje i podejmuje wielokierunkowe działania na poziomie kształcenia kompetencji społecznych, co - jak potwierdzają badania (Nerwińska, 2015) - stanowi zdaniem rodziców bardzo istotną powinność szkoły. Przy okazji nie należy pominąć faktu, że wspólna aktywność na rzecz dobra dziecka stanowi jednocześnie sferę rozwoju dla samych rodziców i nauczycieli. Mogą doświadczać poprzez podjętą współpracę w ramach edukacji wieloi międzykulturowej, rozwoju własnych kompetencji kulturowych. „Aktywność jednostki w ramach współpracy tworzy presję do właściwego komunikowania się, uzasadniania swoich racji, racjonalnego argumentowania, kultury bycia, dyskusji i harmonijnego współgrania w realizacji wspólnego celu" (Opozda, 2017, s. 33) i stanowi jednocześnie wzór kooperacji dla młodszego pokolenia.

\section{Bibliografia}

Chojnacka-Synaszko, B. 2018. Aspekty edukacji wielo- i międzykulturowej uwzględniane w środowisku rodzinnym i szkolnym - na przykładzie doświadczeń polskiej młodzieży z terenu Śląska Cieszyńskiego. Ruch Pedagogiczny. 4/1, ss. 101-117.

Dobrowolska, B. 2015. Postawy nauczycieli wobec edukacji międzykulturowej a kultura szkoty. Studium spoteczno-pedagogiczne. Kraków: Oficyna Wydawnicza „Impuls”.

Dubis, M. 2019. Współpraca: nauczyciel-uczeń-rodzic. Wymiary relacji wychowawczej i edukacyjnej. Studia Paedagogica Ignatiana. 1, Vol. 22, Ss. $149-175$.

Grzybowski, P.P. 2008. Edukacja międzykulturowa - przewodnik. Kraków: Oficyna Wydawnicza „Impuls”.

Januszewska, E., Kulesza, M., Kwiatkowski, M., Odrowąż-Coates, A., Perkowska-Klejman, A. i Wiatr M. 2015. W poszukiwaniu teorii szkoły. Pedagogika Społeczna. 3 (57), ss. 89-112. 
Korczyński, M. 2017. Kompetencje międzykulturowe polskich emigrantów zarobkowych w Anglii. Lubelski Rocznik Pedagogiczny. T. XXXVI, z. 3, Ss. $151-175$.

Lewandowska-Kidoń, T. 2005. Opiekuńczo-wychowawcze zadania szkoły w świetle postanowień reformy edukacji. W: Kępski, Cz. red. Praca opiekuńczo-wychowawcza w szkole i innych instytucjach oświatowych. Lublin: UMCS, ss. 51-60.

Lewowicki, T. 2008. O podstawowych warunkach pomyślnej pracy nauczycieli w sytuacji wielokulturowości. W: Lewowicki, L., Ogrodzka-Mazur, E. i Szczurek-Boruta, A. red. Praca nauczyciela w warunkach wielokulturowości - studia i doświadczenia z pogranicza polsko-czeskiego. Toruń: Wydział Etnologii i Nauk o Edukacji Uniwersytetu Śląskiego, Wyższa Szkoła Pedagogiczna ZNP, Wydawnictwo Adam Marszałek, ss. 13-24.

Lewowicki, T. i Suchodolska, J. 2011. Wstęp. W: Lewowicki, T. i Suchodolska J. red. Dzieci w procesie ksztattowania postaw kulturowych. Przewodnik po ścieżkach edukacji regionalnej, wielo- $i$ międzykulturowej. Katowice - Cieszyn - Warszawa - Kraków: Wydział Etnologii i Nauk o Edukacji Uniwersytetu Śląskiego, Wyższa Szkoła Pedagogiczna ZNP, Oficyna Wydawnicza „Impuls”, ss. 7-9.

Lewowicki, T. 2013. Edukacja wobec odwiecznych i współczesnych problemów świata - konteksty i wyzwania edukacji międzykulturowej. Edukacja Międzykulturowa. 2, ss. 19-37.

Mazur, B. 2012. Kompetencje międzykulturowe w opinii podlaskich menedżerów. Wspótczesne Zarządzanie. 1, ss. 182-191.

Mendel, M. 2007. Rodzice i nauczyciele jako sprzymierzeńcy. Gdańsk: Wydawnictwo Harmonia.

Mendel M. i Wiatr M. 2018. Rodzice siłą demokracji. Pedagogika Społeczna. 4 (70), ss. 207-230.

Nerwińska, E. 2015. Wspótpraca z rodzicami impulsem rozwoju szkoty. Warszawa: Ośrodek Rozwoju Edukacji.

Nikitorowicz, N. 2001. Pogranicze, tożsamość, edukacja międzykulturowa. Białystok: Wydawnictwo Trans Humana.

Ogrodzka-Mazur, E. 2011. Rodzina i dziecko w otoczeniu wielokulturowym. Relacje międzypokoleniowe i ich rola w przekazie wartości. W: Lewowicki, T., Ogrodzka-Mazur, E. i Szczurek-Boruta, A. red. Edukacja międzykulturowa - dokonania, problemy, perspektywy. Cieszyn-Warszawa-Toruń: Wydział Etnologii i Nauk o Edukacji Uniwersytetu Śląskiego, Wyższa Szkoła Pedagogiczna ZNP, Wydawnictwo Adam Marszałek, ss. 15-71. 
Opozda, D. 2017. Synergia rodziny i szkoły - niektóre konteksty teoretyczne i praktyka. Horyzonty Wychowania. 38, Vol.16, ss. 27-40.

Rabczuk, W. 2013. Czynniki niesprzyjające i chroniące w przebiegu kariery szkolnej uczniów imigrantów. Edukacja Międzykulturowa. 2, ss. 38-56.

Radziewicz-Winnicki, A. 2014. Społeczność lokalna, zbiorowość terytorialna a instytucjonalizacja ideologii lokalizmu/regionalizmu. W: Szczurek-Boruta, A., Chojnacka-Synaszko, B. i Suchodolska J. red. Człowiek w przestrzeni lokalnej - dobre praktyki wspierania rozwoju, aktywizacji i integracji społecznej. Toruń: Wydawnictwo Adam Marszałek, ss. 23-38.

Rozporządzenie Ministra Edukacji Narodowej z dnia 6 sierpnia 2019 r. zmieniające rozporządzenie w sprawie wymagań wobec szkół i placówek. $\$ 1$. Suchocka, A. 2016. Kompetencje międzykulturowe - przywilej czy konieczność? Colloquium Wydziału Nauk Humanistycznych i Spotecznych AMW. 4 (24), ss. 121-132.

Śliwerski, B. 2004. Możliwości rozpoznawania sensu współdziałania szkoły, rodziców i uczniów w społeczeństwie wolnorynkowym. W: Nowosad, I. i Szymański M.J. red. Nauczyciele i rodzice. W poszukiwaniu nowych znaczeń i interpretacji wspótpracy. Zielona Góra-Kraków: Oficyna Wydawnicza Uniwersytetu Zielonogórskiego, Akademia Pedagogiczna w Krakowie, ss. 39-56.

\section{Co-participation of parents and teachers in the implementation of the assumptions of multi- and intercultural education - (im)possible solutions}

Abstract: What has been undertaken in this study is the reflection on the important (but still insufficiently explored) collaboration between family and school in the context of extensive cultural diversification. It is emphasized that partner collaboration should enhance the unifying of the influences which contribute to shaping learners' indispensable intercultural competences. Due to this, more significance is attributed to the nature of teachers and parents' engagement in the implementation of the assumptions concerning multi - and intercultural education. As this issue is not much focused on in expert literature, an attempt was made to bring closer the types of their participation in the indicated educational field. This was done taking into account Volker Krumme's concept of the types of parents and teachers' participation in education. The participation considered here comprises both active ("parents get engaged themselves", "teachers get engaged of their own will") and passive ("parents are engaged by teachers", "teachers 
are engaged by parents") commitment of both sides in the implementation of multi - and intercultural education. It was also specified which types of engagement and due to which reasons could be undertaken more or less successfully.

Keywords: coparticipation, family, school, multi - and intercultural education

Translated by Agata Cienciała 